\title{
Falls among elderly persons in Latin America and the Caribbean and among elderly Mexican-Americans
}

\author{
Carlos A. Reyes-Ortiz, ${ }^{1}$ Soham Al Snih, ${ }^{1}$ and Kyriakos S. Markides ${ }^{1}$
}

Suggested citation

Reyes-Ortiz CA, Al Snih S, Markides KS. Falls among elderly persons in Latin America and the Caribbean and among elderly Mexican-Americans. Rev Panam Salud Publica. 2005;17(5/6):362-9.

ABSTRACT Objective. To estimate the prevalence of and risk factors for falls among communitydwelling elders in Latin America and the Caribbean and among elderly Mexican-Americans in the southwestern United States.

Methods. Data for the study came from a project called Health, Well-Being, and Aging in Latin America and the Caribbean (Salud, Bienestar y Envejecimiento en América Latina y el Caribe) (the "SABE project") (surveys from seven cities, with a total of 9765 subjects) and from the Hispanic Established Populations for Epidemiologic Studies of the Elderly (H-EPESE) (1 483 subjects).

Results. The overall prevalence of falls across the seven SABE cities and the H-EPESE ranged from $21.6 \%$ in Bridgetown, Barbados, to $34.0 \%$ in Santiago, Chile. In multiple logistic regression analyses, female gender, increased age, high depressive symptoms, and having any functional limitations were significant independent risk factors for falls in most of the cities studied as well as among the elderly Mexican-Americans. In several of the cities, significant risk factors also included diabetes, urinary incontinence, and arthritis.

Conclusions. The prevalence of falls had a large variation among the countries studied. Some of the risk factors that we identified could be modified so as to help prevent falls in older people in these populations. The factors deserving attention include depressive symptoms, functional limitations, diabetes, and urinary incontinence.

Key words Accidental falls; aged; aged, 80 and over; risk factors; Latin America; Caribbean; Mexican Americans.

A third of people aged 65 and older who live in the community fall each year, and about half of those fallers have multiple falls, according to stud-

\footnotetext{
University of Texas Medical Branch, Galveston, Texas, United States of America. Send correspondence to: Carlos A. Reyes-Ortiz, Division of Geriatric Medicine, Sealy Center on Aging, University of Texas Medical Branch, 301 University Blvd., Galveston, Texas 77555-0460, United States of America; telephone: 409-772-8340; fax: 409-7728931; e-mail: careyeso@utmb.edu
}

ies that have been conducted worldwide (1-6). However, only a few studies on this subject have been reported from Latin America. For example, in a community-dwelling cohort study among people aged 65 and older in the city of São Paulo, Brazil, Perracini and Ramos (7) found that $29 \%$ of subjects had fallen in the preceding year, and $12 \%$ had had recurrent falls. In a community cross-sectional study among women 60 years old or over in the city of Rio de Janeiro, Brazil, Rosenfeld et al. (8) reported a total prevalence of $37 \%$ for falls in the previous year, and $14 \%$ for two or more falls.

Among older people, falls are associated with considerable mortality, hospitalization, institutionalization, hip fractures, fear of falling, and other consequences (4, 9-13). For example, in Brazil during 1995, 41\% of all deaths 
from falls occurred among people 60 or older (8). Similarly, in Jamaica, falls accounted for $41 \%$ of the trauma cases admitted to a rural hospital, and $26 \%$ of the trauma cases admitted to an urban hospital (14). In addition, $62.9 \%$ of elders in Colombia who had fallen developed a fear of falling, and $26 \%$ of them reported functional restrictions on instrumental and social activities of daily living due to that fear (15).

The scientific literature has reported multiple risk factors for falls. These include age, female gender, history of previous falls, use of sedatives, gait impairment, lower- or upper-extremity weakness, functional impairment, sensory impairment, cognitive impairment, history of fracture, lack of periodical physical activity, and such medical conditions as arthritis, diabetes, depression, urinary incontinence, Parkinson's disease, and stroke (1-8, 15-18).

As the number of persons and the proportion of the total population who are older increase in Latin America, falls will become a major health burden (19-21). In the year 2000 the population of people aged 60 years or over in Latin America and the Caribbean was 41.3 million (22), and the estimated number of falls was 13.8 million. In Latin America, as in other parts of the world, falls are a major public health problem, in that they are associated with fractures, fear of falling, disability, extensive use of health services, institutionalization, and increased burden on family members $(7,9,12,14,15,18,23,24)$. Women live longer than men in Latin America do (as elsewhere around the world), but older women in Latin America are more likely than men to be uninsured and to not have social security benefits $(21,22)$. Women face a higher risk for falls and for hip fractures, so public health policies are needed to especially direct resources toward prevention of falls among them.

An analysis of the data collected in 2000-2001 for the Hispanic Established Populations for Epidemiologic Studies of the Elderly (H-EPESE) found a prevalence of falls in the preceding year of $32 \%$ in older MexicanAmericans in the southwestern part of the United States (25). That analysis also found that age, female gender, diabetes, arthritis, impairment in instrumental activities of daily living, and high depressive symptoms were significant independent predictors for one or more falls.

The purpose of our study was to estimate the prevalence of falls and the risk factors associated with falls among elders in Latin America and the Caribbean, and among MexicanAmericans living in the southwestern part of the United States. For our study we employed a cross-sectional analysis of the H-EPESE and of data sets from a multicenter study called Health, WellBeing, and Aging in Latin America and the Caribbean (Salud, Bienestar $y$ Envejecimiento en América Latina y el Caribe) (the "SABE project"). MexicanAmericans compose nearly $60 \%$ of the Hispanic population of the United States, and older Mexican-Americans are one of the fastest growing segments of older persons in the United States. We wanted to compare older Mexican-Americans to the older populations of Latin American and Caribbean cities, to find out if they have common risk factors for falls.

\section{METHODS}

\section{Sample}

As mentioned above, for this study, data were extracted from the SABE study and from the H-EPESE. The SABE study consists of a round of cross-sectional surveys and includes information collected during 19992000 on 10970 men and women aged 60 and older from seven cities of Latin America and the Caribbean: Bridgetown, Barbados; Buenos Aires, Argentina; Havana, Cuba; Mexico City, Mexico; Montevideo, Uruguay; Santiago, Chile; and São Paulo, Brazil (26). Each sample consisted of between 1500 and 2000 target individuals aged 60 or older and their surviving spouse (26). There were 1205 subjects with missing values for the variables included in this analysis, so the total number of subjects in the seven cities included in our analysis was 9765 .
The H-EPESE study is a longitudinal study of 3050 noninstitutionalized Mexican-American men and women who were aged 65 or older at baseline (1993-1994) and who live in five states in the southwestern United States: Arizona, California, Colorado, New Mexico, and Texas. Sampling and data collection are described elsewhere (27). Subjects were first interviewed in 1993-1994 and followed up two, five, and seven years later. The H-EPESE data employed in this analysis came from the fourth wave, conducted during 2000-2001, when data on falls was collected; there were 1483 subjects then aged 71 and older included in the analysis.

\section{Measures}

Outcome variable. The prevalence of falls in the SABE study was assessed by the following question: "Have you fallen down in the last 12 months?" A positive response was followed by "How many times have you fallen?" In the H-EPESE study, prevalence of falls was assessed by the following question: "During the past 12 months, how many times did you fall and land on the floor or ground?" To report the prevalence of falls in both the SABE and H-EPESE studies, fall status was categorized as one fall, two or more falls, and total prevalence of falls. For our bivariate and multivariate analyses, fall status was dichotomized as no falls vs. one or more falls, for both the SABE and H-EPESE studies.

Predictor variables. In both $\mathrm{SABE}$ and H-EPESE, there were seven categories for predictors of falls that were examined: sociodemographic variables, medical conditions, vision, hearing, functional status, depressive symptoms, and cognitive status.

The sociodemographic variables included age, gender, and marital status.

Medical conditions were assessed with a series of questions asking the respondents if they had been told by a doctor that they had arthritis, diabetes mellitus, a heart attack, hypertension, stroke, cancer, or urinary incontinence. 
In the SABE study, distant vision was evaluated by the question "Is your vision to see things far away (like recognize a friend on the other side of the street) excellent, very good, good, fair, or poor?" Good, fair, or poor was coded as having a distant-vision problem. Near vision was evaluated by the question "Is your vision to see things close up (like to read a newspaper or to look at photographs in a magazine) excellent, very good, good, fair, or poor?" Good, fair, or poor was coded as having a near-vision problem. In the H-EPESE, distant vision was evaluated by the question "Can you see well enough to recognize a friend across the street and across the room?" A response of no was coded as having a distant-vision problem. Near vision was evaluated by the question "Can you see well enough to recognize who is at an arm's length away?" A response of no was coded as having a near-vision problem.

In the SABE study, hearing was evaluated by the question "In general, would you say that your hearing is excellent, very good, good, fair, or poor?" Good, fair, or poor was coded as having a hearing problem. In the H-EPESE, hearing was evaluated by the question "Can you usually hear and understand what a person says without seeing his face if that person talks in a normal voice to you in a quiet room?" A response of no was coded as having a hearing problem.

Functional status was assessed by seven activities of daily living items (ADLs): walking across a small room, bathing, grooming, dressing, eating, transferring from a bed to a chair, and using the toilet (28). Subjects were asked if they did not need help, they needed help, or they were unable to perform the activity. ADL disability was dichotomized as no help needed versus needing help with or being unable to perform one or more of the seven ADL activities.

Depressive symptomatology was measured with the Geriatric Depression Scale (GDS) (29) in the SABE study, and with the Center for Epidemiologic Studies Depression Scale (CES-D) (30) in the H-EPESE study. The
GDS contains 15 items, with a score from 0 to 15 . Conventionally, the cutoff point for mild depressive symptoms is a score of 6, and for severe depressive symptoms the cutoff point is 11 (29). For the CES-D a score of 16 or over indicates high depressive symptomatology (31). Both the GDS and the CES-D were used as continuous variables in our bivariate and multivariate analyses.

In the SABE study, cognitive status was evaluated by the abbreviated MiniMental State Examination (AMMSE), which was validated in the Chilean population (26). The AMMSE consists of 9 items (versus the 19 items of the MMSE), and has a score from 0 to 19 . In the H-EPESE, cognitive status was evaluated using the Mini-Mental State Examination (MMSE), with a score of 0 to 30 (32). Both the AMMSE and the MMSE were used as continuous variables in our bivariate and multivariate analyses.

\section{Data analysis}

For bivariate comparisons the chisquare test for categorical variables and the $t$ test for continuous variables were performed. A multivariate logistic regression analysis was used to estimate the odds of falls, comparing people without falls to people who had fallen at least once.

To evaluate the influence of cumulative risk factors on the risk of falling, we made additional analyses. Based on the adjusted logistic model findings, we constructed a summary score based on the main risk factors (where all variables must be dichotomous): age $\geq 80$ years, female gender, high depressive symptoms (dichotomized as GDS $\geq 11$ for the SABE study, and CES-D $\geq 16$ for the H-EPESE study) $(29,31)$, diabetes mellitus, urinary incontinence, and any ADL impairment. Then, the risk of falling according to the number of risk factors (from 0 to 6 ) found in the adjusted analyses was examined. We constructed four categories: 0, 1, 2 and $3+$ risk factors. Trends of falls according to these four categories were assessed by the Mantel-Haenszel chisquare test.
The analyses incorporated weighted data, except for Bridgetown and the H-EPESE. All analyses, including weighted and unweighted analyses, were performed using the SAS System for Windows version 8.2 software (SAS Institute, Inc., Cary, North Carolina, United States).

\section{RESULTS}

Figure 1 shows that the highest prevalence of falls was reported in Santiago (34.0\%), and the lowest in Bridgetown $(21.6 \%)$. The highest prevalence of persons with multiple falls (that is, two or more) was also in Santiago $(20.3 \%)$, and the lowest again in Bridgetown (8.7\%).

Tables $1 \mathrm{a}$ and $1 \mathrm{~b}$ present the bivariate comparison of fallers (one or more falls) and nonfallers. Fallers were significantly more likely to be older, be female, be ADL disabled, have lower cognitive scores, and report higher depressive symptoms, urinary incontinence, hypertension, arthritis, diabetes mellitus, distant-vision problems, and hearing problems.

Table 2 shows the results of the multiple logistic regression analyses. Significant independent risk factors for one or more falls were female gender (all surveys, odds ratio (OR) from 1.36 to 2.34), age (six surveys: Bridgetown, São Paulo, Santiago, Havana, Mexico City, and Montevideo; all have OR of 1.02), higher depressive symptoms (six settings: Bridgetown, São Paulo, Havana, Mexico City, Montevideo, and Mexican-Americans; OR from 1.02 to 1.10), any ADL limitation (five surveys: Bridgetown, Santiago, Havana, Montevideo, and Mexican-Americans; OR from 1.46 to 2.04), arthritis (three surveys: Bridgetown, Havana, and Montevideo; OR from 1.31 to 1.65), urinary incontinence (three surveys: Buenos Aires, Santiago, and Havana; OR from 1.39 to 1.96), diabetes (three surveys: Bridgetown, São Paulo, and Mexico City; OR from 1.33 to 1.49 ), and heart attack (two surveys: Santiago and Montevideo; OR 1.59 and 1.50 , respectively). In contrast, a decreased risk for falls was found for 
FIGURE 1. Prevalence of falls among elderly persons in seven cities of Latin America and the Caribbean and among Mexican-Americans in the southwestern United States

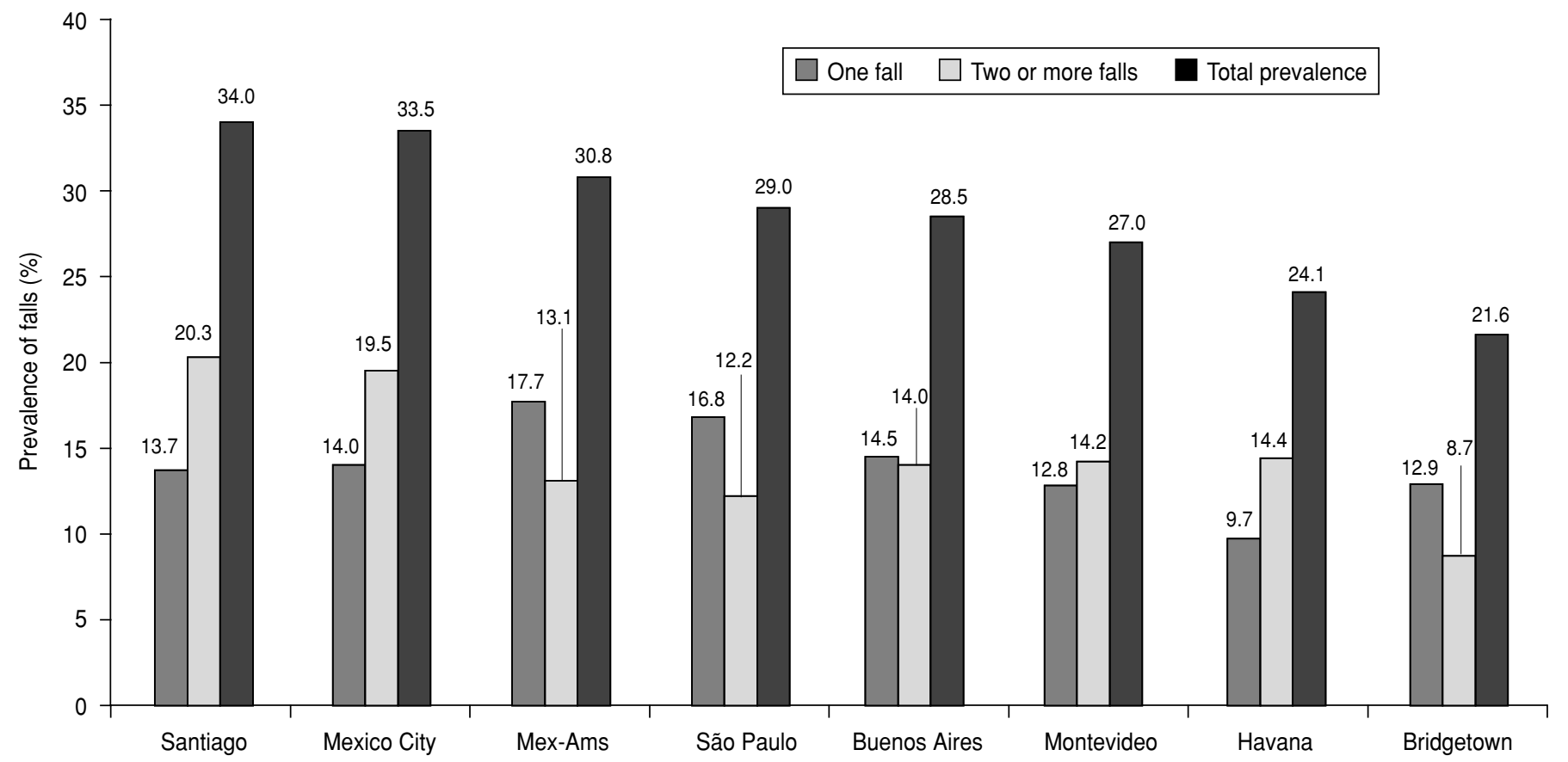

TABLE 1a. Bivariate comparison, for sociodemographic factors and medical conditions, of fallers vs. nonfallers from four cities in Latin America and the Caribbean

\begin{tabular}{|c|c|c|c|c|c|c|c|c|}
\hline \multirow[b]{3}{*}{ Characteristic } & \multirow{2}{*}{\multicolumn{2}{|c|}{$\begin{array}{c}\text { Buenos Aires, Argentina } \\
(n=964)\end{array}$}} & \multirow{2}{*}{\multicolumn{2}{|c|}{$\begin{array}{c}\text { Bridgetown, Barbados } \\
\quad(n=1635)\end{array}$}} & \multirow{2}{*}{\multicolumn{2}{|c|}{$\begin{array}{c}\text { São Paulo, Brazil } \\
(n=1777)\end{array}$}} & \multirow{2}{*}{\multicolumn{2}{|c|}{$\begin{array}{c}\text { Santiago, Chile } \\
\qquad(n=1205)\end{array}$}} \\
\hline & & & & & & & & \\
\hline & $\begin{array}{c}\text { Fallers } \\
(n=275)\end{array}$ & $\begin{array}{c}\text { Nonfallers } \\
(n=689)\end{array}$ & $\begin{array}{l}\text { Fallers } \\
(n=353)\end{array}$ & $\begin{array}{c}\text { Nonfallers } \\
(n=1282)\end{array}$ & $\begin{array}{l}\text { Fallers } \\
(n=516)\end{array}$ & $\begin{array}{l}\text { Nonfallers } \\
(n=1261)\end{array}$ & $\begin{array}{l}\text { Fallers } \\
(n=410)\end{array}$ & $\begin{array}{c}\text { Nonfallers } \\
(n=795)\end{array}$ \\
\hline Age $(y r)(\text { mean } \pm S D)^{a}$ & $71.4 \pm 7.0^{c}$ & $69.9 \pm 6.7$ & $73.0 \pm 7.9^{c}$ & $71.5 \pm 7.7$ & $69.4 \pm 6.9^{c}$ & $68.3 \pm 6.8$ & $71.3 \pm 7.6^{c}$ & $69.6 \pm 7.7$ \\
\hline Female $(\%)$ & $74.2^{\mathrm{d}}$ & 57.6 & $70.8^{d}$ & 56.9 & $68.4^{\mathrm{d}}$ & 54.9 & $68.7^{\mathrm{d}}$ & 54.8 \\
\hline Married (\%) & 95.1 & 94.5 & 80.0 & 83.4 & 95.4 & 95.6 & 94.1 & 93.1 \\
\hline Heart attack (\%) & 22.7 & 18.9 & 13.9 & 10.9 & $23.0^{\mathrm{b}}$ & 18.0 & $42.2^{\mathrm{d}}$ & 27.9 \\
\hline Hypertension (\%) & $56.4^{\mathrm{b}}$ & 48.0 & $55.2^{\mathrm{c}}$ & 47.0 & 55.7 & 51.8 & $60.2^{d}$ & 47.7 \\
\hline Stroke (\%) & $7.9^{d}$ & 2.6 & $6.5^{b}$ & 4.0 & 6.9 & 4.9 & $9.0^{c}$ & 4.8 \\
\hline Cancer (\%) & 6.3 & 5.1 & 4.8 & 3.5 & 2.6 & 3.2 & 4.0 & 3.5 \\
\hline Urinary incontinence $(\%)$ & $19.0^{\mathrm{d}}$ & 6.8 & $12.8^{\mathrm{c}}$ & 7.5 & $23.5^{\mathrm{d}}$ & 15.3 & $29.9^{d}$ & 17.6 \\
\hline Depression score $(\text { mean } \pm S D)^{e}$ & $3.3 \pm 3.2^{d}$ & $2.4 \pm 2.7$ & $2.0 \pm 2.1^{d}$ & $1.6 \pm 1.6$ & $3.7 \pm 3.2^{d}$ & $3.0 \pm 3.1$ & $4.2 \pm 3.6^{b}$ & $3.7 \pm 3.5$ \\
\hline
\end{tabular}

a $\mathrm{SD}=$ standard deviation.

b $P<0.05$.

${ }^{\mathrm{C} P}<0.01$.

d $P<0.001$

${ }^{\mathrm{e}}$ Depression: the Geriatric Depression Scale (GDS) was used for these four Latin America and Caribbean cities.

f Cognitive test: the abbreviated Mini-Mental State Examination was used for these four Latin America and Caribbean cities.

${ }^{g} \mathrm{ADL}=$ activity of daily living.

heart attack (two surveys: Mexico City and the Mexican-Americans; OR 0.59 and 0.55 , respectively), and higher cognitive function (two surveys: Havana and Mexico City; OR 0.95 and 0.94 , respectively).
Table 3 shows the occurrence of falls according to the number of risk factors. Risk factors included age $\geq 80$ 
TABLE 1b. Bivariate comparison, for sociodemographic factors and medical conditions, of fallers vs. nonfallers from three cities in Latin America and the Caribbean and among Mexican-Americans in the southwestern United States

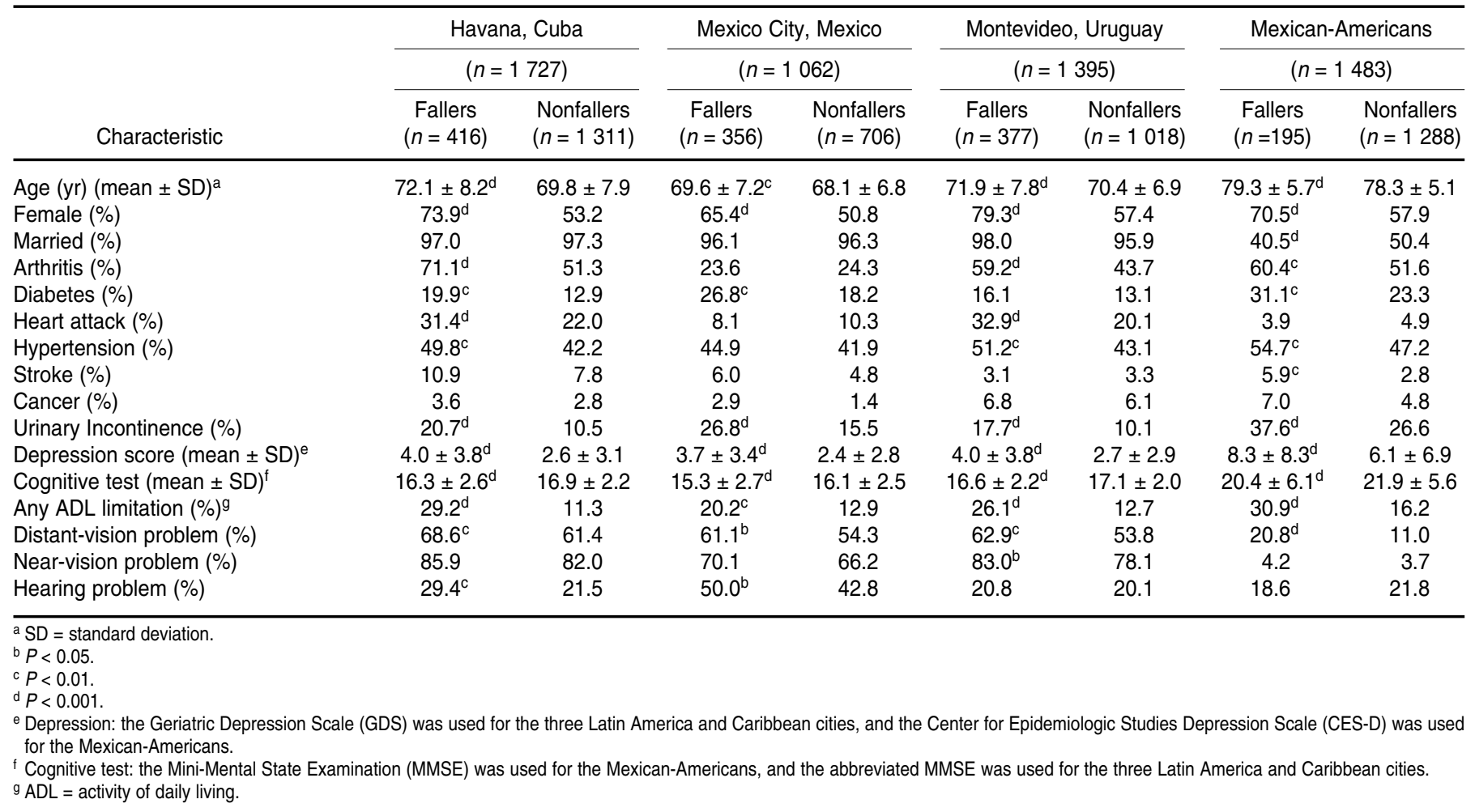

TABLE 2. Odds ratio (OR), with $95 \%$ confidence interval $(95 \% \mathrm{Cl})$, of falls vs. no falls by sociodemographic characteristics and medical conditions in seven cities of Latin America and the Caribbean and among Mexican-Americans in the southwestern United States

\begin{tabular}{|c|c|c|c|c|c|c|c|c|}
\hline & $\begin{array}{c}\text { Buenos Aires, } \\
\text { Argentina }\end{array}$ & $\begin{array}{c}\text { Bridgetown, } \\
\text { Barbados }\end{array}$ & $\begin{array}{l}\text { São Paulo, } \\
\text { Brazil }\end{array}$ & $\begin{array}{l}\text { Santiago, } \\
\text { Chile }\end{array}$ & $\begin{array}{c}\text { Havana, } \\
\text { Cuba }\end{array}$ & $\begin{array}{c}\text { Mexico City, } \\
\text { Mexico }\end{array}$ & $\begin{array}{c}\text { Montevideo, } \\
\text { Uruguay }\end{array}$ & Mex-Americans \\
\hline Risk factor & OR $\quad(95 \% \mathrm{Cl})$ & OR $\quad(95 \% \mathrm{Cl})$ & $\mathrm{OR} \quad(95 \% \mathrm{Cl})$ & OR $\quad(95 \% \mathrm{Cl})$ & OR $\quad(95 \% \mathrm{Cl})$ & OR $\quad(95 \% \mathrm{Cl})$ & OR $(95 \% \mathrm{Cl})$ & OR $\quad(95 \% \mathrm{Cl})$ \\
\hline Age (years) & $1.02(0.99-1.04)$ & $1.02(1.00-1.03)$ & $1.02(1.00-1.03)$ & $1.02(1.00-1.04)$ & $1.02(1.01-1.04)$ & $1.02(1.00-1.04)$ & $1.02(1.01-1.04)$ & $1.02(0.99-1.04)$ \\
\hline Female & $2.01(1.42-2.83)$ & $1.58(1.20-2.08)$ & $1.60(1.27-2.01)$ & $1.36(1.02-1.80)$ & $1.82(1.39-2.38)$ & $1.82(1.37-2.42)$ & $2.34(1.75-3.14)$ & $1.42(1.09-1.86)$ \\
\hline Married & $1.42(0.72-2.82)$ & $0.87(0.64-1.19)$ & $0.91(0.55-1.50)$ & $1.34(0.79-2.27)$ & $0.89(0.44-1.81)$ & $1.15(0.58-2.32)$ & $2.15(0.97-4.79)$ & $0.09(0.69-1.16)$ \\
\hline Arthritis & $1.15(0.83-1.57)$ & $1.37(1.06-1.77)$ & $1.19(0.94-1.49)$ & $1.33(0.99-1.77)$ & $1.65(1.26-2.14)$ & $0.69(0.50-0.97)$ & $1.31(1.01-1.70)$ & $1.14(0.90-1.45)$ \\
\hline Diabetes & $1.51(0.96-2.36)$ & $1.39(1.05-1.84)$ & $1.33(1.02-1.74)$ & $0.99(0.69-1.44)$ & $1.23(0.89-1.69)$ & $1.49(1.08-2.06)$ & $1.07(0.75-1.52)$ & $1.28(0.98-1.67)$ \\
\hline Heart attack & $1.03(0.70-1.50)$ & $1.08(0.74-1.56)$ & $1.19(0.91-1.55)$ & $1.59(1.22-2.07)$ & $1.13(0.86-1.50)$ & $0.59(0.36-0.97)$ & $1.50(1.12-2.00)$ & $0.55(0.31-0.99)$ \\
\hline Hypertension & $1.06(0.78-1.45)$ & $1.14(0.88-1.47)$ & $0.97(0.77-1.20)$ & $1.41(1.09-1.83)$ & $1.06(0.82-1.36)$ & $0.95(0.72-1.26)$ & $1.06(0.81-1.37)$ & $1.14(0.89-1.45)$ \\
\hline Stroke & $3.37(1.66-6.84)$ & $1.25(0.73-2.15)$ & $1.23(0.79-1.92)$ & $1.16(0.68-1.98)$ & $1.10(0.73-1.65)$ & $1.20(0.66-2.17)$ & $0.57(0.28-1.17)$ & $1.59(0.89-2.82)$ \\
\hline Cancer & $1.06(0.56-2.00)$ & $1.21(0.68-2.18)$ & $0.69(0.36-1.32)$ & $0.71(0.36-1.40)$ & $1.12(0.58-2.15)$ & $2.67(1.03-6.93)$ & $0.83(0.50-1.37)$ & $1.42(0.88-2.30)$ \\
\hline Urinary incontinence & $1.96(1.22-3.14)$ & $1.20(0.79-1.80)$ & $1.18(0.89-1.55)$ & $1.42(1.04-1.94)$ & $1.39(1.00-1.94)$ & $1.40(0.99-1.99)$ & $1.21(0.84-1.75)$ & $1.28(0.99-1.66)$ \\
\hline Depression score ${ }^{\mathrm{a}}$ & $1.05(0.99-1.11)$ & $1.08(1.01-1.15)$ & $1.04(1.01-1.08)$ & $1.03(0.99-1.07)$ & 1.05 (1.02-1.09) & $1.10(1.05-1.15)$ & $1.09(1.04-1.13)$ & $1.02(1.00-1.04)$ \\
\hline Cognitive test score ${ }^{b}$ & $0.99(0.92-1.07)$ & $1.01(0.95-1.07)$ & $1.02(0.97-1.07)$ & $0.99(0.95-1.03)$ & $0.95(0.90-0.99)$ & $0.94(0.89-0.99)$ & $0.96(0.90-1.02)$ & $0.99(0.97-1.01)$ \\
\hline Any ADL limitation ${ }^{c}$ & $1.51(0.99-2.29)$ & $1.76(1.24-2.51)$ & $1.31(0.98-1.74)$ & $1.47(1.03-2.10)$ & $2.04(1.52-2.75)$ & $1.14(0.77-1.67)$ & $1.46(1.04-2.04)$ & $1.57(1.17-2.01)$ \\
\hline Distant-vision problem & $0.84(0.61-1.15)$ & $1.20(0.92-1.57)$ & $1.14(0.92-1.43)$ & $1.17(0.90-1.53)$ & $0.98(0.75-1.28)$ & $1.02(0.76-1.36)$ & $1.13(0.86-1.47)$ & $1.73(1.22-2.45)$ \\
\hline Near-vision problem & $1.07(0.73-1.55)$ & $0.98(0.74-1.31)$ & $0.87(0.64-1.17)$ & $1.30(0.93-1.80)$ & $1.11(0.79-1.58)$ & $1.19(0.88-1.60)$ & $1.11(0.79-1.55)$ & $0.61(0.32-1.16)$ \\
\hline Hearing problem & $1.39(0.92-2.08)$ & $1.19(0.87-1.64)$ & $1.23(0.97-1.56)$ & $0.82(0.61-1.10)$ & $1.15(0.87-1.52)$ & $1.18(0.89-1.56)$ & $0.82(0.59-1.13)$ & $0.75(0.56-1.01)$ \\
\hline
\end{tabular}

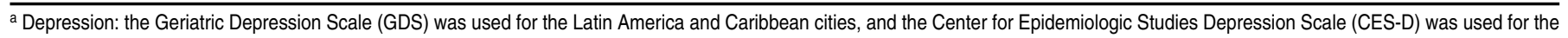
Mexican-Americans.

${ }^{b}$ Cognitive test: the Mini-Mental State Examination (MMSE) was used for the Mexican-Americans, and the abbreviated MMSE was used for the Latin America and Caribbean cities.

${ }^{c} \mathrm{ADL}=$ activity of daily living.

years, female gender, high depressive symptoms (GDS $\geq 11$ or CES-D $\geq 16$ ), diabetes mellitus, urinary inconti- nence, and any ADL impairment. A significant increase $(P<0.0001)$ in the occurrence of falls was seen as the number of risk factors increased in all the surveys, when considering the categories of $0,1,2$, and $\geq 3$ risk factors. 
TABLE 3. Trend of falls (\% of persons who had fallen) according to the number of risk factors among elderly persons in seven cities of Latin America and the Caribbean and among elderly Mexican-Americans in the southwestern United States ${ }^{\mathrm{a}}$

\begin{tabular}{|c|c|c|c|c|c|c|}
\hline \multirow[b]{2}{*}{ City/Population } & \multicolumn{4}{|c|}{ Number of risk factors } & \multicolumn{2}{|c|}{ Test for trend ${ }^{b}$} \\
\hline & 0 & 1 & 2 & $3+$ & $x^{2}$ & $P$ value \\
\hline Buenos Aires & 12.8 & 27.8 & 39.9 & 49.5 & 62.5 & $<0.0001$ \\
\hline Bridgetown & 12.1 & 19.7 & 27.6 & 40.4 & 57.9 & $<0.0001$ \\
\hline São Paulo & 16.9 & 26.8 & 33.5 & 44.3 & 63.0 & $<0.0001$ \\
\hline Santiago & 19.8 & 30.8 & 41.0 & 46.5 & 44.5 & $<0.0001$ \\
\hline Havana & 10.0 & 20.9 & 31.7 & 46.9 & 123.3 & $<0.0001$ \\
\hline Mexico City & 18.1 & 32.4 & 41.5 & 50.8 & 48.8 & $<0.0001$ \\
\hline Montevideo & 11.4 & 22.7 & 38.2 & 43.2 & 83.0 & $<0.0001$ \\
\hline Mexican-Americans & 16.6 & 23.0 & 32.3 & 44.5 & 64.9 & $<0.0001$ \\
\hline
\end{tabular}

${ }^{a}$ Risk factors included age $\geq 80$ years, female gender, high depressive symptoms (Geriatric Depression Scale $\geq 11$ for the Latin American and Caribbean cities, Center for Epidemiologic Studies Depression Scale $\geq 16$ for the Mexican-Americans), diabetes mellitus, urinary incontinence, and any activity of daily living limitation.

b Test for trend done using Mantel-Haenszel chi-square test.

\section{DISCUSSION}

Our investigation found that the estimated prevalence of one or more falls in the SABE study and in the H-EPESE study had a wide variation across sites, from $21.6 \%$ in Bridgetown to $34.0 \%$ in Santiago. However, the range that we found was close to that reported in other countries $(27 \%$ to $36 \%)(1,2,4)$, as well as for older Mexican-American women in the state of California (32\%) (6).

The prevalence levels of subjects who had multiple falls (two or more) that were found in five of the seven SABE cities (Bridgetown, Havana, Montevideo, Buenos Aires, and São Paulo) and in the H-EPESE ranged from $8.7 \%$ to $14.4 \%$. These levels were similar to those of older populations in the developed countries of Canada, Finland, and the United States, where the prevalences of multiple falls among older people have been reported to be between $10 \%$ and $15 \%(2,4,11)$. Similarly, studies in Brazil found prevalence levels of multiple falls among older persons of $12 \%$ (7) and 14\% (8). Two of the SABE cities had higher prevalences of multiple falls: Mexico City (19.5\%) and Santiago (20.3\%).

We found that being older, being female, and having any functional impairments were significant independent correlates of falls in most of the survey sites. These findings are consistent with other studies, where age, fe- male gender, and functional impairment were the main risk factors for falls among older people living in the community (1, 3-7, 18, 33-37).

A high level of depressive symptoms was an independent risk factor for falls in Bridgetown, São Paulo, Havana, Mexico City, and Montevideo, and in Mexican-Americans. These findings are similar to those reported from studies done in Italy, the Netherlands, and the United States $(1,38,39)$. However, because we did not include antidepressive medication use in this analysis, we could not determine if the increased risk for falls is due to depression or to the effect of medications.

Diabetes was an independent risk factor for falls in Bridgetown, São Paulo, and Mexico City. In a few other studies, done in the United States, diabetes has been reported as a risk factor for falls $(3,40)$. Arthritis was an independent risk factor for falls in Bridgetown, Havana, and Montevideo. This is similar to some previous studies done in the United States $(3,6,37)$. Urinary incontinence was a risk factor for falls in Buenos Aires, Santiago, and Havana; these findings agree with previous reports on research done in and Japan (41) and in the United States $(42,43)$.

Other independent risk factors for falls that we found were heart attack in Chile and Uruguay, stroke in Buenos Aires, hypertension in Santiago, distant-vision problems in the H-EPESE Mexican-Americans, and cancer in Mexico City. We found previous reports for vision problems, stroke, and cancer $(5,7,43-45)$, but not for hypertension or heart attack.

We found that that high cognitive status is a protective factor for falls in Havana and Mexico City. These results are consistent with previous reports from Brazil (16), Canada (2), and the United States (4) that dementia and cognitive impairment are risk factors for falls in older people.

Our findings that arthritis (in Mexico City) and heart attack (in Mexico City and in the H-EPESE MexicanAmericans) were associated with a decreased risk for falls could have several possible explanations. One is the restricted activities in these subjects, and another is the use of cardiac medications that reduce symptoms that are associated with falls. In a study done in Canada the use of cardiac medications was associated with decreased risk for falls (5). The authors proposed that cardiac medications reduced fallrelated symptoms such as dizziness secondary to decreased heart output. However, the SABE and H-EPESE studies collected no data on specific cardiac medications that we could have used to confirm this association between cardiac medications and decreased risk for falls.

Our study has some limitations. The SABE and H-EPESE data on falls and comorbidities were self-reported. However, self-reports of falls and medical conditions have been used in many studies, and have been found to be accurate and reliable $(1,3,5,37)$. Another limitation is our reliance on crosssectional data, which precludes establishing causal relationships between certain variables and falls. Also, injury data related to falls and environmental barriers were not available in our analysis; this somewhat limits the meaningfulness of our results for these populations. Finally, the SABE survey does not represent the diversity of environments, localities, and elderly that exist in the selected countries. That is because the SABE data were collected in larges cities, with the exception of Bridgetown, which has a much smaller population than do the other SABE cities. 
One important contribution of our study is the demonstration that the risk for falls increases with age. Our study also shows that higher risk results from the accumulated effect of multiple conditions. Indeed, the risk of falls increased linearly with the number of risk factors, and that trend was significant for all seven SABE cities and for the Mexican-Americans.

This is the first comparative analysis of falls in Latin America and the Caribbean and in the MexicanAmerican population of the southwestern United States. We found that older Mexican-Americans, who comprise the largest population of older Hispanics in the United States, share some risk factors for falls with older populations from Latin American and Caribbean cities. These shared risk factors include female gender, higher depressive symptoms, and any ADL limitation.

We hope that our results will encourage additional research on this emerging public health problem. Two potentially treatable conditions were significant independent predictors of falls. This was true for symptoms of depression in five cities: Bridgetown, São Paulo, Havana, Mexico City, and
Montevideo. It was also true for diabetes in three cities: Bridgetown, São Paulo, and Mexico City. High cognitive performance was protective for falls in two cities (Havana and Mexico City). These particular findings indicate that to prevent falls across Latin America and the Caribbean countries, public health policies regarding the early treatment of depression and diabetes in older people will be helpful. In addition, promoting education and other activities to maintain cognitive function in elders in Latin American and Caribbean might help decrease the risk of falling (46).

The results of our study may also help to design specific health policies within each country. A particular concern comes up regarding the highest prevalences of falls, which were found in Santiago and Mexico City. For example, our finding that heart attacks and hypertension are risk factors in Santiago suggests the need for interventions targeting people with these conditions. And in Mexico City a priority should be to target older people with diabetes, which is a highly prevalent disease in Mexico.

In conclusion, our results showed that the prevalence of falls is high in
Latin America and the Caribbean and in Mexican-Americans in the southwestern United States. The risk for falls increases with age and may result from the accumulated effect of multiple conditions. A major implication of this study is that early detection of risk factors for falls may decrease the incidence of falls in these populations. Indeed, falls are associated with disability and medical conditions of high prevalence in Latin American and the Caribbean and in older MexicanAmericans, such as diabetes, arthritis, and depression-and all these conditions could be prevented, treated, or managed better.

Acknowledgments. This study was supported by Grant AG10939 (Hispanic Established Populations for Epidemiologic Studies of the Elderly) funded by the National Institute on Aging, Grant P50 CA105631 (University of Texas Medical Branch Center for Population Health and Health Disparities) funded by the National Institutes of Health and the National Cancer Institute, and Grant AT002849 funded by the National Center for Complementary and Alternative Medicine, National Institutes of Health.

\section{REFERENCES}

1. Cesari M, Landi F, Torre S, Onder G, Lattanzio F, Bernabei R. Prevalence and risk factors for falls in an older community-dwelling population. J Gerontol Med Sci. 2002;57A(11): M722-6.

2. Fletcher PC, Hirdes JP. Risk factors for falling among community-based seniors using home care services. J Gerontol Med Sci. 2002;57A(8): M504-10.

3. Hanlon JT, Landerman LR, Fillenbaum GG, Studenski S. Falls in African American and White community-dwelling elderly residents. J Gerontol Med Sci. 2002;57A(7): M473-8.

4. Tinetti ME, Speechley M, Ginter SF. Risk factors for falls among elderly persons living in the community. New Engl J Med. 1988;319 (26):1701-7.

5. O'Loughlin JL, Robitaille Y, Boivin JF, Suissa $S$. Incidence of and risk factors for falls and injurious falls among the community-dwelling elderly. Am J Epidemiol. 1993;137(3):342-54.

6. Schwartz AV, Villa ML, Prill M, Kelsey JA, Galinus JA, Delay RR, et al. Falls in older Mexican-American women. J Am Geriatr Soc. 1999;47(11):1371-8.
7. Perracini MR, Ramos LR. Fatores associados a quedas em uma coorte de idosos residentes na comunidade. Rev Saude Publica. 2002;36(6) 709-16.

8. Rozenfeld S, Camacho LAB, Veras RP. Medication as a risk factor for falls in older women in Brazil. Rev Panam Salud Publica. 2003; 13(6):369-75.

9. De Lena S, Barbieri N, Cuacci S, Diamante A. Encuesta de camas geriátricas municipales de hospitales polivalentes en la provincia de Buenos Aires: análisis de la situación de los ancianos institucionalizados. Med Soc. 1999; 22(3/4):158-73.

10. Espino DV, Palmer RF, Miles TP, Mouton CP, Wood RC, Bayne NS, et al. Prevalence, incidence, and risk factors associated with hip fractures in community-dwelling older Mexican Americans: results of the Hispanic EPESE study. Establish Population for the Epidemiologic Study for the Elderly. J Am Geriatr Soc. 2000;48(10):1252-60.

11. Kannus P, Parkkari J, Koskinen S, Niemi S, Palvanen $M$, Jarvinen $M$, et al. Fall-induced injuries and deaths among older adults. JAMA. 1999;281(20):1895-9.
12. Mosquera MT, Maurel DL, Pavón S, Arregui A, Moreno C, Vázquez J. Incidencia y factores de riesgo de la fractura de fémur proximal por osteoporosis. Rev Panam Salud Publica. 1998; 3(4):211-9.

13. Young Y, Myers AH, Provenzano G. Factors associated with time to first hip fracture. J Aging Health. 2001;13(4):511-26.

14. McDonald AH, Dawkins N, Titus IP. Patterns of trauma injuries in rural versus urban Jamaica. West Indian Med J. 2001;50(3):214-7.

15. Curcio CL, Gómez JF, García A. Caídas y capacidad funcional entre ancianos colombianos que realizan y no realizan ejercicio. Colomb Med. 1998;29(4):125-8.

16. Carvalho A de M, Coutinho ESF. Demência como fator de risco para fraturas graves em idosos. Rev Saude Publica. 2002;36(4):448-54.

17. Coutinho ESF, Silva SD. Uso de medicamentos como fator de risco para fratura grave decorrente de queda em idosos. Cad Saude Publica. 2002;18(5):1359-66.

18. González G, Marín PP, Pereira G. Características de las caídas en el adulto mayor que vive en la comunidad. Rev Med Chile. 2001;129(9): 1021-30. 
19. Palloni A, Pinto-Aguirre G, Pelaez M. Demographic and health conditions of ageing in Latin America and the Caribbean. Int J Epidemiol. 2002;31(4):762-71.

20. Marin PP, Wallace SP. Health care for the elderly in Chile: a country in transition. Aging Clin Exp Res. 2002;14(4):271-7.

21. Reyes-Ortiz CA. The health conditions of the elderly in Colombia: an overview. Clin Geriatr. 2000;8(5):61-6.

22. Guzmán JM. Envejecimiento y desarrollo en América Latina y el Caribe. Santiago, Chile: Centro Latinoamericano y Caribeño de Demografía; 2002. (Serie Población y Desarrollo No. 28).

23. Pelaez M. More need for the "old" in new public health research in the Americas. Rev Panam Salud Publica. 2003;13(6):352-4.

24. Reyes-Ortiz CA. The disability-poverty connection in older people. J Natl Med Assoc. 1999;91(2):75-7.

25. Reyes-Ortiz CA, Al Snih S, Loera J, Ray LA, Markides KS. Risk factors for falling in older Mexican Americans. Ethn Dis. 2004;14(3): 417-22.

26. Albala $C$, Lebrão ML, León Díaz EM, HamChande R, Hennis A, Palloni A, et al. Encuesta Salud, Bienestar y Envejecimiento (SABE): metodología de la encuesta y perfil de la población estudiada. Rev Panam Salud Publica. 2005;17(5/6):307-22.

27. Markides KS, Stroup-Benham CA, Black S, Satish S, Perkowski L, Ostir G. The health of Mexican American elderly: selected findings from the Hispanic EPESE. In: Wykle ML, Ford $\mathrm{AB}$, eds. Serving minority elders in the 21st century. New York: Springer Publishing Company, Inc.; 1999. Pp. 72-90.

28. Katz SC, Ford AB, Moskowitz RW, Jackson BA, Jaffe MW. Studies of illness in the aged: the index of ADL, a standardized measure of biological and psychosocial function. JAMA. 1963;185:914-9.

29. Sheikh JI, Yesavage JA. Geriatric Depression Scale: recent evidence and development of a shorter version. Clin Gerontol. 1986;5:165-72.

30. Radloff LS. The CES-D scale: a self-report depression scale for research in the general population. Appl Psychol Measur. 1977:1:385-401.

31. Boyd JH, Weissman M, Thompson W, Myers JK. Screening for depression in a community sample. Arch Gen Psychiatry. 1982;39(10): 1195-200.

32. Folstein MF, Folstein SE. Mini-Mental State: a practical method for grading the cognitive state of patients for the clinician. J Psychiatric Res. 1975;12(3):189-98.

33. Aoyagi K, Ross PD, Davis JW, Wasnich RD, Hayashi T, Takemoto T-I. Falls among community-dwelling elderly in Japan. J Bone Miner Res. 1998;13(9):1468-74.

34. Blake AJ, Morgan K, Bendal MJ, Dallosso H, Ebrahim SBJ, Arie THD, et al. Falls by elderly people at home: prevalence and associated factors. Age Ageing. 1988;17(6):365-72.

35. Langlois JA, Smith GS, Nelson DE, Sattin RW, Stevens JA, DeVito CA. Dependence in activities of daily living as a risk factor for fall injury events among older people living in the community. J Am Geriatr Soc. 1995;43(3): 275-8.

36. Marín PP, Kornfeld R, Escobar MC. Medición del riesgo funcional de adultos mayores pobres, con instrumento validado en Canadá. Rev Med Chile. 1998;126(11):1316-22.

37. Nevitt MC, Cummings SR, Kidd S, Black D. Risk factors for recurrent nonsyncopal falls: a prospective study. JAMA. 1989;261(18): 2663-8.

38. Stalenhoef PA, Diederiks JPM, Knottnerus JA, Kester ADM, Crebolder HFJM. A risk model for the prediction of recurrent falls in community-dwelling elderly: a prospective cohort study. J Clin Epidemiol. 2002;55(11): 1088-94.

39. Whooley MA, Kip KE, Cauley JA, Ensrud KE, Nevitt M, Browner WS. Depression, falls, and risk of fracture in older women. Study of Osteoporotic Fractures Research Group. Arch Intern Med. 1999;159(5):484-90.

40. Schwartz AV, Hillier TA, Sellmeyer DE, Resnick HE, Gregg E, Ensrud KE, et al. Older women with diabetes have a higher risk of falls: a prospective study. Diabetes Care. 2002; 25(10):1749-54

41. Yasumura $S$, Haga $H$, Nagai $H$, Suzuki $T$, Amano H, Shibata H. Rate of falls and the correlates among elderly people living in an urban community in Japan. Age Ageing. 1994; 23(4):323-7.

42. Brown JS, Vittinghoff E, Wyman JF, Stone KL, Nevitt MC, Ensrud KE, et al. Urinary incontinence: does it increase risk for falls and fractures? Study of Osteoporotic Fractures Research Group. J Am Geriatr Soc. 2000;48(7): 721-5.

43. Rekeneire N, Visser M, Peila R, Nevitt MC, Cauley JA, Tylavsky FA, et al. Is a fall just a fall: correlates of falling in healthy older persons. The Health, Aging and Body Composition Study. J Am Geriatr Soc. 2003;51(6):841-6.

44. Holley S. A look at the problem of falls among people with cancer. Clin J Oncol Nursing. 2002;6(4):193-7.

45. Ivers RQ, Cumming RG, Mitchell P, Attebo K. Visual impairment and falls in older adults: the Blue Mountain Study. J Am Geriatr Soc. 1998;46(1):58-64.

46. Reyes-Ortiz CA. Delirium, dementia and brain reserve. J Am Geriatr Soc. 1997;45(6): 778-9.

Manuscript received 29 June 2004. Revised version accepted for publication 11 April 2005.
RESUMEN

Las caídas en ancianos de América Latina y el Caribe y en ancianos mexicanoestadounidenses

Palabras clave
Objetivo. Estimar la prevalencia de caídas y de sus factores de riesgo en ancianos que habitan en el seno de la comunidad en América Latina y el Caribe y en ancianos mexicanoestadounidenses que viven en la zona sudoeste de Estados Unidos.

Métodos. Los datos usados para el estudio procedieron del proyecto Salud, Bienestar y Envejecimiento en América Latina y el Caribe (proyecto "SABE") (encuestas en siete ciudades que abarcaron a un total de 9765 personas) y de las Poblaciones Hispanas Establecidas para Estudios Epidemiológicos en Ancianos [Hispanic Established Populations for Epidemiologic Studies of the Elderly (H-EPESE)] (1 483 personas).

Resultados. La prevalencia general de caídas en personas de edad en las siete ciudades que participaron en el proyecto SABE varió de 21,6\% en Bridgetown, Barbados, a 34,0\% en Santiago, Chile. Según análisis de regresión logística, el ser de sexo femenino, tener más edad, y tener síntomas de depresión profunda o alguna limitación funcional fueron factores de riesgo asociados de forma independiente y estadísticamente significativa con las caídas en personas de edad en la mayor parte de las ciudades estudiadas, así como en ancianos mexicanoestadounidenses. En varias ciudades también fueron factores de riesgo estadísticamente significativos la diabetes, la incontinencia urinaria y la artritis.

Conclusiones. La prevalencia de caídas varió mucho entre los países estudiados. Algunos de los factores de riesgo identificados se podrían modificar a fin de prevenir las caídas en personas de edad avanzada en estas poblaciones. Los factores a los que se debe prestar atención son los síntomas de depresión, las limitaciones funcionales, la diabetes y la incontinencia urinaria.

Accidentes por caídas; anciano; ancianos de 80 años y más; América Latina; Caribe; Americanos Mexicanos. 